\title{
VIII. IN MEMORIAM
}

\section{Profesor Jerzy Walachowicz (1932-2014)}

W dniu 11 września 2014 r. zmarł Jerzy Walachowicz, profesor zwyczajny nauk prawnych, historyk prawa, jeden $\mathrm{z}$ nestorów polskiego środowiska historyków prawa, wieloletni kierownik Katedry Historii Ustroju Państwa na Wydziale Prawa i Administracji Uniwersytetu im. Adama Mickiewicza w Poznaniu. Był wybitnym badaczem, zasłużonym nauczycielem akademickim, oddanym wychowawcą młodzieży i działaczem społecznym. Jego odejście jest niepowetowaną stratą i budzi głęboki żal.

Jerzy Walachowicz był przez całe życie związany z Poznaniem. W Poznaniu się w 1932 r. urodził, uczęszczał do szkół, tu też studiował. Tylko w ostatnich latach dojeżdżał do Szczecina, by na tamtejszym Wydziale Prawa i Administracji wykładać historię ustroju i prawa. Był dumny ze swych poznańskich i robotniczych korzeni, które wyrażały treści głęboko patriotyczne i katolickie. Jego ojciec był żołnierzem kampanii wrześniowej i trafił do niewoli niemieckiej. Zginął w ostatnich dniach wojny w czasie wyzwalania Poznania. Jerzy wcześnie został głównym żywicielem rodziny, w tym brata Tadeusza, który później został profesorem teologii i historii prawa na Uniwersytecie im. Adama Mickiewicza.

Jerzy Walachowicz był człowiekiem prawym, pracowitym, rzetelnym i skromnym, życzliwym ludziom. Cechy charakteru Profesora nie tylko zjednywały Mu szacunek i sympatię, ale także pozwoliły, w trudnych, powojennych warunkach, ukończyć studia i rozpocząć blisko 50-letnią karierę akademicką.

Miał szczęście, bo przyszło mu studiować w okresie, gdy poznański Wydział Prawa mógł poszczycić się mianem najlepszego po Krakowie ośrodka badań historycznoprawnych w Polsce. Rozkwitała w tym czasie poznańska szkoła historycznoprawna, związana z działalnością profesorów: Zygmunta Wojciechowskiego, Józefa Matuszewskiego, Zdzisława Kaczmarczyka, docenta Stefana Weymana oraz mistrza J. Walachowicza - profesora Michała Sczanieckiego. To właśnie prof. Michał Sczaniecki, jeden z najwybitniejszych historyków państwa i prawa po wojnie, miał decydujący wpływ na naukowe wybory Profesora. Będąc zaledwie jednym $\mathrm{z}$ trzech magistrantów, a następnie 
jedynym doktorantem Sczanieckiego, pod jego wpływem Jerzy Walachowicz zainteresował się dziejami ustroju i prawa Pomorza Zachodniego. Wykłady i seminaria tych luminarzy nauk historycznoprawnych budowały klimat, w którym nie było miejsca na intelektualną bierność. To właśnie oni ukształtowali formację naukową i zbudowali fundamenty pod przyszłe sukcesy Profesora Walachowicza i Jego uczniów.

Zaciągnięty wobec mistrzów w trakcie studiów dług intelektualny Jerzy Walachowicz zaczął spłacać bardzo szybko. Już pierwszy swój artykuł, opublikowany na łamach „Czasopisma Prawno-Historycznego” w 1957 r., poświęcił rozwojowi immunitetu sądowego na Pomorzu Zachodnim. Rozprawa ta, jak i opublikowane kilka lat później obszerne studium dotyczące immunitetu ekonomicznego w tej dzielnicy w okresie wczesnofeudalnym, są najbardziej zakorzenione $\mathrm{w}$ tradycji prowadzonych w Poznaniu badań nad immunitetami przez profesorów Zygmunta Wojciechowskiego, Józefa Matuszewskiego i Zdzisława Kaczmarczyka. Stanowią one rozszerzenie terytorialne badań wymienionych autorów o teren Pomorza Zachodniego.

Podjętej w tych pierwszych opracowaniach tematyce, wzbogaconej następnie o naukową analizę różnych instytucji ustrojowych państwa średniowiecznego, Profesor Walachowicz pozostał wierny do końca. I chwała mu za to, biorąc pod uwagę niepokojące zjawisko wyraźnego zaniku zainteresowań mediewistycznych w polskim świecie naukowym $\mathrm{w}$ ostatnich kilkudziesięciu latach. Chwała mu również i za to, że żmudnie budując niełatwy warsztat historyka ustroju średniowiecza, nie wahał się podejmować prac na „,naukowym ugorze", tematów trudnych, czytelnikowi polskiemu dotąd nie znanych, rzetelnych naukowo dzięki iście benedyktyńskiej staranności i dbałości o prawdę historyczną.

Bibliografia prac Jubilata liczy blisko 100 pozycji, wśród których reprezentowane są wszystkie gatunki naukowego pisarstwa: monografie, obszerne studia, artykuły i recenzje, współautorstwo w 16 księgach dedykowanych wybitnym polskim historykom państwa i prawa, podręczniki i pomoce dydaktyczne w postaci wyborów tekstów źródłowych do nauki historii ustroju państwa i historii prawa, a także artykuły o charakterze popularnonaukowym ${ }^{1}$.

Zainteresowania naukowe Jerzego Walachowicza koncentrowały się wokół problematyki historii ustrojów państwowych państw feudalnych, w tym przede wszystkim Pomorza Zachodniego, Nowej Marchii i Brandenburgii. Polem swoich dociekań badawczych uczynił m.in. zagadnienia: historii dochodów państwa wczesnofeudalnego, niemieckiej ekspansji ustrojowej na wschodzie $\mathrm{w}$ tej epoce, historii zarządu terytorialnego, dziejów egzempcji sądowych i ekonomicznych, organizacji terytorialnej i uposażenia Kościo-

${ }^{1}$ Zob. bibliografię prac Profesora w: Studia z historii ustroju i prawa. Księga dedykowana profesorowi Jerzemu Walachowiczowi, pod red. H. Olszewskiego, Poznań 2002, s. 5-12. 
ła. W Jego dorobku naukowym na szczególną uwagę zasługują monografie poświęcone monopolom książęcym w skarbowości wczesnofeudalnej Pomorza Zachodniego, landwójtostwu na Pomorzu Zachodnim i kształtowaniu się zarządu terytorialnego w dobie pokasztelańskiej, genezie i ustrojowi politycznemu Nowej Marchii do początku XIV w., seria artykułów dotyczących regaliów w Brandenburgii (regale mennicze, grodowe i młynne), obszerne studium na temat ustroju państwowego Brandenburgii w okresie askańskim, prace ukazujące wczesne dzieje diecezji kamieńskiej i lubuskiej.

Jego badania, poświęcone bez reszty ustrojowi północno-zachodnich ziem dzisiejszej Rzeczypospolitej, poza walorami stricte naukowymi, mają także jeszcze inny niezwykłej doniosłości wymiar. „Prowadzą one bowiem do ukazywania historycznej słowiańskości i polskości tych ziem, które w średniowieczu ujarzmione zostały przez Niemców i wydarte Słowiańszczyźnie" - jak pisał profesor K. Orzechowski. Profesor Walachowicz swoimi pracami przerwał milczenie polskich historyków w tej sprawie, pokazując całą anatomię „Drang nach Osten”.

Właśnie dziś lektura Jego prac powinna służyć lepszemu zrozumieniu historii stosunków polsko-niemieckich, bez czego trudno o dobrą współpracę w jednoczącej się Europie. I chyba ten pogląd podzielał J. Walachowicz w jednym z ostatnich swoich artykułów, pisząc:

„Prace na temat historii ustroju politycznego Brandenburgii w obecnej sytuacji, zmierzającej ku integracji europejskiej, wydają się ze wszech miar uzasadnione i potrzebne. Zapełniają bowiem lukę zarówno w nauce, jak i w świadomej, wzajemnej współpracy. Skoro regiony mają ze sobą współgospodarować, to oczywistą wydaje się rzeczą, że najpierw powinny się wzajemnie poznać, i to nie tylko od strony realiów współczesnych, ale i dawniejszej tradycji, która znajduje wyraz w toku długich dziejów, wzajemnego i bezpośredniego sąsiedztwa i tkwi najpewniej w głębokich pokładach świadomości Niemców i Polaków”.

Na szczególną uwagę zasługuje to, że w Jego spuściźnie naukowej nie ma prac, które nie byłyby oparte na źródłach łacińskich czy staroniemieckich. Z upartą konsekwencją wystrzegał się opracowań bazujących tylko na literaturze przedmiotu. Wyjątkowa znajomość źródeł, duża umiejętność korzystania z nich, sumienność dokumentacji formułowanych tez, to cechy Jego naukowego pisarstwa.

Autor stosował też w swych badaniach metodę statystyczną i porównawczą. Ważne ,pracowite tabelki”, będące dowodem skłonności Autora do ilościowego traktowania badanych zjawisk, pozwalały Mu opierać obserwacje na pewnych podstawach, kładąc przy tym wyraźną granicę między konstatacjami a hipotezami.

Istotną cechą warsztatu pracy badawczej Profesora Walachowicza było rozpatrywanie badanej problematyki na szerokim tle porównawczym. Pozwa- 
lało $\mathrm{Mu}$ to na ujmowanie badanych zjawisk w pełniejszy sposób, na uzupełnianie analogiami, a także wykrywanie ich cech swoistych oraz umieszczanie wyników prac w szerszym kontekście. Skala porównań obejmowała u Profesora Walachowicza zwykle Europę środkową, południową i wschodnią (Rzesza Niemiecka, kraje niemieckie - Meklemburgia, Brandenburgia, księstwa saskie, Słowiańszczyzna południowa - zarówno znajdująca się w orbicie kultury łacińskiej, jak i bizantyjskiej, wreszcie Ruś). Towarzyszyła temu zasada przedstawiania analizowanych zagadnień w ścisłym związku z uwarunkowaniami społecznymi, ekonomicznymi i ustrojowymi. Stanowiło to, jak przed laty pisał profesor K. Orzechowski - ,przykład nowej metody ujmowania zjawisk i instytucji prawnych w ścisłym powiązaniu z gospodarką, przy zastosowaniu swoistego wyjęcia przed nawias badanych zagadnień".

Twórczość naukowa Profesora Walachowicza konsekwentnie wpisuje się w tradycje poznańskiej szkoły historycznoprawnej. W zakresie swych fascynacji naukowych był kontynuatorem znakomitych osiągnięć swych poprzedników, na obszarach niezbadanych przez nich monograficznie ziem północnozachodnich Rzeczypospolitej. Nikt przed Nim, spośród polskich historyków państwa i prawa, nie poświęcił tyle badawczej uwagi i nie dostarczył nam tak rzetelnej wiedzy o historii ustroju tych ziem.

W pisarstwie Profesora Walachowicza znajdujemy też publikacje na tematy dydaktyczne, to dla potrzeb dydaktyki pisane interesujące badania statystyczne postępów i efektywności nauczania w relacji do egzaminu wstępnego. Podziw budzi Jego dorobek w zakresie edycji źródeł służących poznaniu historii ustroju państwa i prawa, przedsięwzięcia podjętego jeszcze w 1969 r., wspólnie z profesorem Bogdanem Lesińskim, doskonalonego w kolejnych wydaniach aż do schyłku lat dziewięćdziesiątych. Te wydawnictwa źródłowe zostały zaopatrzone $\mathrm{w}$ instruktywne wstępy do poszczególnych, starannie dobranych tekstów, od nowa tłumaczonych przez Profesora z języków: łacińskiego, angielskiego, niemieckiego i rosyjskiego. Prezentowane źródła dotyczą wielu państw świata i najistotniejszych zagadnień historii państwa i prawa. Od ponad 30 lat służą do prowadzenia konwersatoriów, wykładów i seminariów ze studentami prawa. Trzeba przyznać, że są do tego celu niesłychanie przydatne, podobnie jak podręczniki do historii ustroju państwa z pierwszej połowy lat dziewięćdziesiątych, których Profesor był współautorem i redaktorem.

Nieobca też była Profesorowi Walachowiczowi niełatwa sztuka popularyzacji wiedzy historycznej. Dał tego dowód choćby w cyklu artykułów publikowanych na łamach miesięcznika społeczno-kulturalnego „Nad Odrą”, poświęconych historii ziem leżących nad środkową Odrą oraz dolną Wartą i Notecią, szkicami dotyczącymi katolickiego ruchu uniwersytetów ludowych i szkolnictwa poznańskiego, a także swojej małej ojczyzny - podpoznańskich Smochowic. 
Charakterystyka dorobku Profesora Walachowicza nie byłaby pełna, gdyby chociaż kilku zdań nie poświęcić Jego osiągnięciom na polu dydaktycznym i kształcenia młodej kadry naukowej. Przez 45 - lat Pan Profesor był wykładowcą na poznańskiej wszechnicy, od 1986 r. również na Uniwersytecie Szczecińskim. Prowadził również zajęcia w punktach konsultacyjnych w Koszalinie, Gdańsku, Gdyni, Zielonej Górze, Kaliszu i Lesznie. Wypromował ponad 100 magistrów i 5 doktorów, wielokrotnie uczestniczył w różnych rolach w przewodach doktorskich, habilitacyjnych, profesorskich. Wobec studentów był zawsze wymagający, ale i sprawiedliwy, a wobec nas - kolegów, zawsze życzliwy i gotowy podać pomocną dłoń.

Po przejściu na emeryturę Profesor nie zerwał kontaktów ani z Katedrą, ani z Wydziałem. Uczestniczył w naukowych posiedzeniach Katedry, zawsze uważnie słuchany. Pojawiał się na uroczystościach wydziałowych. Z wielką radością uczestniczył zarówno w Wigiliach jak i noworocznych spotkaniach seniorów z JM Rektorem.

Profesor J. Walachowicz nie uchylał się też od obowiązków organizacyjnych. W latach 1981-1984 był prodziekanem Wydziału. Od 1985 do 1987 r. oraz w latach 1990-2002 kierował Katedrą Historii Ustroju Państwa. Był też członkiem Zarządu Poznańskiego Towarzystwa Przyjaciół Nauk, Towarzystwa Naukowego Instytutu Zachodniego im. Zygmunta Wojciechowskiego oraz Komitetu Nauk Prawnych PAN (1993-1996).

Odznaczony był Krzyżem Kawalerskim Orderu Odrodzenia Polski, Złotym Krzyżem Zasługi, Medalem Komisji Edukacji Narodowej oraz Odznaką Gryfa Pomorskiego.

Odejście Profesora Jerzego Walachowicza jest dla nas bolesną stratą.

KRZYSZTOF KRASOWSKI (Poznań) 
